\title{
DEAR READER -
}

It's a great pleasure to introduce the new Swarthmore International Relations Journal.

Swarthmore students have long been engaged in international issues, from setting up organizations like the Genocide Intervention Network to working on War News Radio. The creation of SIRJ continues this important tradition. The journal is student written, edited, and produced. It offers students a major new opportunity to communicate their work more widely through the college and beyond. The style of article - scholarly but punchy and policy relevant - should attract wide interest.

The articles in the first edition of SIRJ are exceptionally timely, and cover major issues facing the Obama administration: ISIS propaganda, the role of the UN Security Council after the Cold War, National Security strategy, U.S. Cuban relations, Russian policy in Crimea, energy policy, cyber warfare, and the refugee crisis.

I hope to see SIRJ become a major vehicle for student writing on international relations for years to come.

- Dominic Tierney, Professor of Political Science Swarthmore College 